Sexual and gender diversity in small cities: LGBT experiences in Girona, Spain

Jose Antonio Langarita Adiego ${ }^{\mathrm{a}}$

${ }^{a}$ University of Girona, Girona, Spain.

Faculty of Education and Psychology, Plaça Sant Domènec, 917004 Girona, josan.langarita@udg.edu

Jose Antonio Langarita Adiego holds a PhD. in Social Anthropology. He is an associal professor at the University of Girona, where he works at Applied Social Scieces ese ch Group. His interest includes the intersection between sexuality, gender and spect nd discriminations by gender expression, gender identity and sexual orientan. yas published his works in various international journals in English, French and Spdis. well as books and book chapters. He has been the principal investigator in several punded by the European Union and currently is working on a new project about Sexp ander Diversity in Childhood.

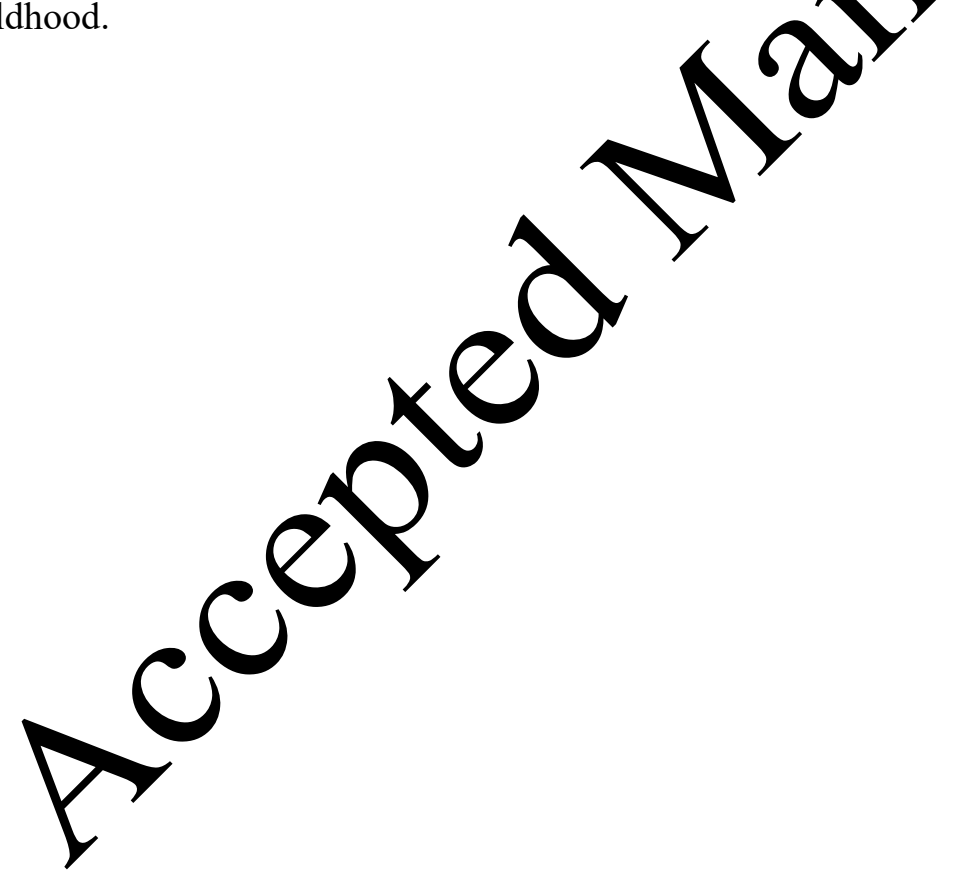




\section{Sexual and gender diversity in small cities: LGBT experiences in Girona, Spain}

Big cities have become the preeminent area for studies on sexual and gender diversity. Major Western cities dominate the panorama of stories, discourses and practices regarding sexual and gender diversity in urban studies. However, many LGBT people reside outside of large cities. This paper intends to challenge the hegemony of the 'big city' as the intrinsic center of production of discourse what is meant by 'LGBT' and to analyze how social relationships among 1 BD people emerge in the environment of a medium-sized city. To this ent, $>$ ethnographic research, including interviews and participant obs rvation, was conducted for my research. One of the main conclusions frot that, despite the fact that big cities play a dominant role in the co struction of LGBT lifestyles, aspirations and desires, there are other I $A$ Barratives outside of big cities that deserve to be considered in order to pryia y more complex and nuanced understanding of sexual and gen di sity. This research challenges the assumption that LGBT life outs city is associated with isolation, loneliness and discomfort, as demonyte that many LGBT people who live outside the big city are conten aby their everyday lives.

Keywords: LGBT stula s; sexualities; small cities; LGBT experiences; homophobia; Urb stydies

\section{Introduction}

Urban studifstharrave focused on the experiences of LGBT people have done so in the conte bigerties (Aldrich 2004; Bell and Binnie 2004; Black et al. 2002; Hubbard and Wilkin on 2015; Kanai 2014; Nash 2013; Sibalis 2004; Higgs 1999; Gorman-Murray and Nash 2017; Nash and Gorman-Murray 2017). Furthermore, in some of these studies, the big city has been presented as the location for LGBT people's lives, the 'natural' destination of sexual minorities from rural areas and small cities eager to find a community of reference to connect with (Weston 1995; Baley 1998; Abraham 2009). Some authors go so far as to claim that LGBT people can only achieve a fulfilling life in the 'big city' (Doderer 2011). Likewise, there are those who suggest that the big city is where the modern gay identity is constructed, and it is what shapes the lifestyle of men 
who have sex with other men (Bech 1997; Chauncey 1994; Hindle 1994). However, there are at least four problems worth noting in connection with these assumptions. The first is that big city experiences are not uniform for all LGBT people; there are significant differences between the experiences of gay, lesbian, bisexual or trans people which merit further investigation (Nash and Gorman-Murray 2015; Nash 2010; Podmore 2001; Podmore and Chamberland 2015; Doan 2010, 2007; Browne and Lim 2010). The second problem is that differences also exist in the interplay between other forms of oppression (Casey 2016, Callander, Newman and Holt 2015, Irazábal and Huerta 2016 and Rosenbeg 2017). Third, not all big cities share the same social and cultural features. Fina $y$ and rather obviously, not all LGBT people live in big cities.

Despite this, the history of sexual diversity in the West, nan tives of LGTQ $_{\text {GBT }}$ communities continues to be constructed and associated wh cities. Large international events, June 28 parades, and the spaces of socjollzation (bars, clubs, shops, neighborhoods) aimed at LGBT populations, help to month LGBT visibility as a predominantly big city phenomenon. This has led to th idea that LGBT people who live outside of metropolitan centers have made a for cerron and have yet to find liberation. Wienke and Hill $(2013,1257)$ observersion is that rural gay men and lesbians are at a disadvantage, both ocially psychologically, when compared to their urban counterparts.' Likewise, sn@lly ytowns and rural areas are presented as more intolerant about gender and s a diversity than the big cities, where LGBT people appear to find a greater of acceptance (Binnie 2004). In this way, the classic dichotomy of urban and studies are reproduced, with the rural representing the opposite of the $y_{0}$ is $\mathfrak{t}$ dichotomy that has little to do with reality. It has already been challendarious academic works (Champion and Hugo 2016; Bryant and Pini 2011 and to minimize or overlook the role of small cities. Indeed, Halberstam (2005) Coes so far as to use the notion of 'metronormativity' to refer to the privileges associated with metropolitan centers where such normativities are reproduced. Nevertheless, compound words that include normativity remain problematic. Podmore (2016) believes - in the case of lesbians - that the notion of metronormativity leads to a questionable and reductive dualism between the rural and the urban. Meanwhile, Brown (2012, 2008) criticizes Duggan's notion of homonormativity (2002), considering that the analyses regarding sexual and gender diversity are too complex and contradictory for them to be theorized through a concept that pretends to reconcile a whole mass of situations that are overrun by social reality. 
In any case, a gradually increasing number of studies are appearing that dispute the hegemony of the big city as a space for LGBT people. This work calls into question the discourses, representations and practices that associate LGBT exclusively with large urban environments (Bell 2000; Browne 2011; Kuhar and Švab 2014; McPhail 2008; Mcglynn 2018; Herring 2010; Rodó de Zárate 2015; Abelson 2016; Gray, Johnson, and Gilley 2016). These studies represent a change in direction from the conventional concepts of sexuality in urban spaces, focusing on scenarios far from the big cities. Furthermore, by incorporating territoriality into these intersectional analyzes many of them are broadening and enriching the debate on the relevance of space in the haing of social, cultural and sex-gender relationships (Johnston 2018).

One issue not yet fully explored is how the big city narrative a subjectivities among LGBT people in small cities. In this article lloying perspectives, such as those advanced by Browne (2008) and Kazyak (201), ing aim is to explore the impact of the big city on the subjectivities of people who sin small towns or cities. The focus of our study is the city of Girona, in the orm east of Spain, which has a population of 99,013 .

We focus on people who live in iron, ry ther than those who have left to larger cities. This is not to deny the exis/ence of so-called 'sexile' of LGBT people to big cities, or to other countries, where g gater degree of acceptance of sexual and gender diversity may be found (GuzQn) 1997; Martinez-San Miguel 2011). The migratory processes of LGBT people big cities have been widely documented and discussed (Langarita Adiego and S louero Velázquez 2016; La Fountain-Stokes 2004; Annes and Redlin 2012; Carail ald Pontdevila 2014; Chávez 2011; Hibbins 2005; Smith 2012). Neverthelesse is not for everyone; not all LGBT people leave their towns for the big cry Reding small-town LGBT life to the phenomenon of sexile helps to keep the experidices of the LGBT people in such towns and rural areas invisible, which is precisely what this article hopes to challenge and overcome.

\section{Methodology}

The results presented in this article are derived from a research project called DIVERCITY. Preventing and combating homo- and transphobia in small and medium cities across Europe. Our qualitative work is based on in-depth interviews (involving 17 LGBT people and 11 stakeholders in the city); two discussion groups (one with five LGBT participants, and the other with eight stakeholders) and various observation 
sessions in the city and in a bar, which was a LGBT meeting place but is now closed, as well as in political organizations of LGBT collectives and associations. The observation sessions consisted of regular visits to the only openly LGBT-friendly bar in the city. During these visits, contact was made with some of the informants who were later interviewed. Contacts were also made through participation in various public events of protest and awareness-raising carried out by LGBT organizations in the city and attendance, as a guest member, of the meetings of Girona City Council's LGBT committee, which brings together LGBT organizations and other social agents of the city to address issues of interest to LGBT people at the local level. In addition, gay or ated online social networks (such as Grindr) were also used in order to initiate nntact with potential participants for the research.

The interviews and the discussion groups were both uiddd using a semistructured script, thus facilitating the organization and moniving of the information gathered. In looking for LGBT participants, diversification ditg ma were followed in order to find people with a range of different socio-de graphic characteristics, sexual orientations and gender identities or expr ciond yersification criteria were also followed in selecting stakeholders froprafor professions and types of services, public administrations or representive orgnizations. Likewise, the discussion groups themselves were configured to Co, yjer the sociodemographic diversity of the participants and their sexualites In the case of the stakeholders, the types of organizations and the pocifio sof those who participated are listed in Tables 1 and 2. Both the interviews and heup conversations were transcribed and coded in order to facilitate andentanalysis.

emait or telo one numbers of possible participants were provided by some of the NGOs in the but also by people we met during participant observation sessions in the city, both public and online, resulting in snowball sampling which brought us into contact with new participants. In the case of stakeholders, access was achieved through the search for specific services run by local and regional administrations and LGBT organizations. This research has followed the ethical research standards for social science and all participants gave their informed consent regarding their involvement. Any references that may identify the individuals involved have been anonymized, when these participants have so requested. The field work was carried out over a period of 14 months between December, 2015 and January, 2017. 


\section{The context}

The city of Girona is the capital city of the Province of Girona. The city is home to a large proportion of the province's most important services, such as district hospitals, public administration and the area's public university, which makes it an important hub for the people from the rest of the province when it comes to administrative arrangements, cultural and leisure activities, study or work. The city is known for its strong support for Catalan independence, and its streets are replete with slogans and posters demanding the independence of Catalonia, as well as the release of Catalan political prisoners bis where in Catalonia, the city of Girona is generally seen as a markedly bourgeois that has a high purchasing power. GDP per capita for the year 2016 is, in fact, fnifieanty higher in the city $(€ 38,200$ p.a.) than it is in Catalonia as a whole (€30, 00 y.a.), according to the Statistical Institute of Catalonia (IDESCAT). However the is home to people from very different social groups, with different econgreans. Although the quantitative economic data indicates that the $x$ is prosperous, Girona has neighborhoods where levels of poverty remain wery and which are far-removed from the picture of bourgeois contentment wibuled, 6 the city. Furthermore, there is the adjoining town of Salt (pop. 29.83 which, yhile having its own municipal council, has very close economic and social tie wy Girona. Even so, the GDP per capita of Salt is considerably lower (€30,000 in 20 b), being more in line with the average figure across Catalonia.

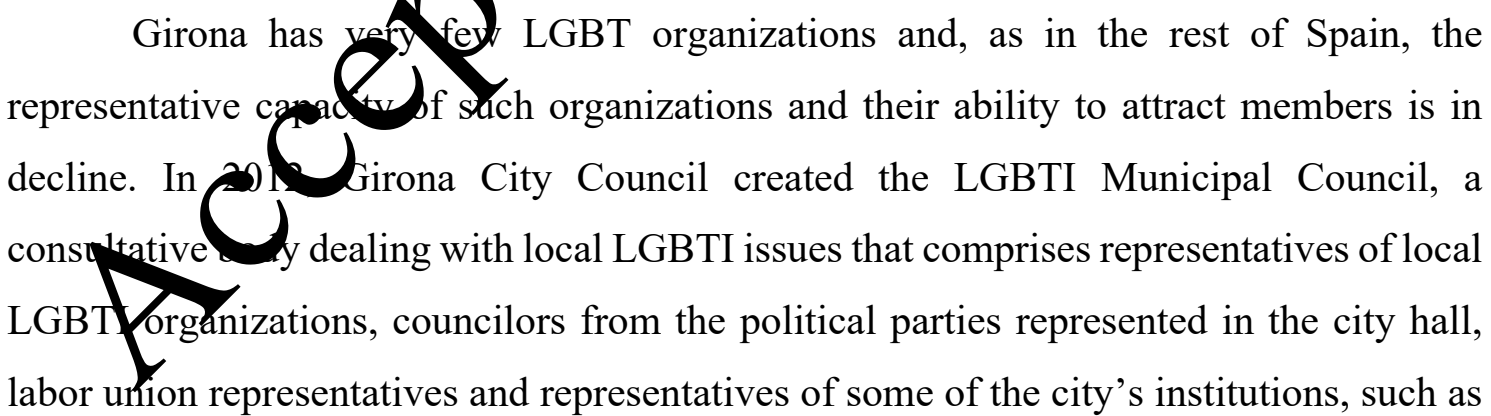
the University of Girona, among others.

Official discourse and action concerning sexual diversity is limited in the city, and tends to only involve symbolic celebrations of special days for the LGBT community, such as the International Day Against LGBT-phobia (May $17^{\text {th }}$ ), LGBT Pride Day (June $28^{\text {th }}$ ), or World AIDS Day (December $1^{\text {st }}$ ). The fact that Girona is only 100 kilometers away from Barcelona means there is mutual influence between the cities. Many LGBT people travel to Barcelona for work or study but also at weekends to openly experiment 
with their sexual identity or gender expression. However, the one and a half-hour drive, the expense and restricted schedules of public transport - the last train from Barcelona to Girona leaves before 10:00 in the evening - reduces the influence of Barcelona on Girona; and means, for example, that a 'night out' in the big city is not always viable.

Girona is a small city and forms of social control are very significant in the lives of people, since there is little anonymity among the inhabitants of the city. Friends or acquaintances are almost always to be found in public areas. In short, sexual expressions that are not heterosexual or gender identities that are not cisgender, fare rarely visible in the city, although they have increased in recent years.

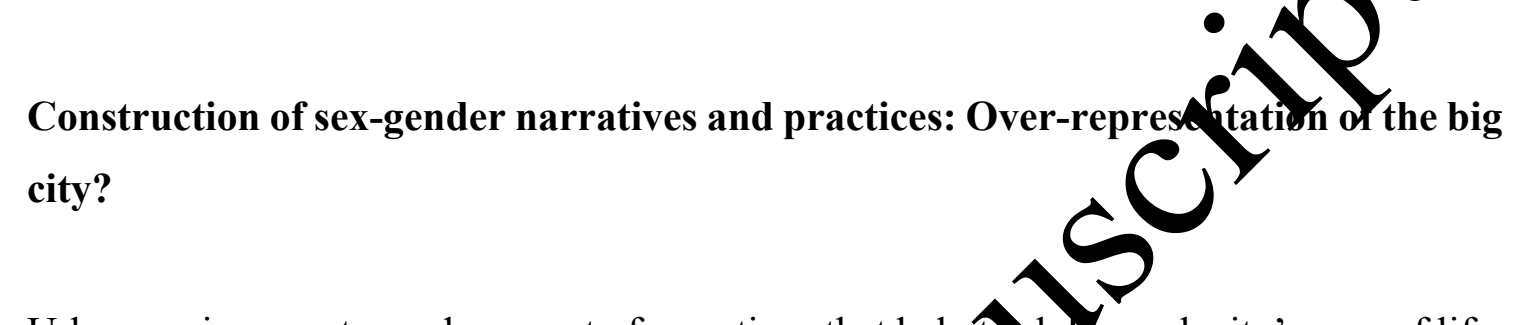

Urban environments produce a set of narratives that heln to hojpe each city's way of life. These narratives, which have a markedly heterosexua focds in terms of production and control (Bell and Valentine 1995), are configh Vilgoluntless cultural, social, economic, demographic and environmental elen atso, others. In recent decades, LGBT narratives have become more visibj, espechyly in big cities. Big cities provide increased opportunities in terms of leisure, s cia zation, anonymity and sexual partners (Hubbard 2012). However, above all, the tgnd to centralize the representations, discourses and practices of what is considere 'GGBT'. In other words, despite the manifold experiences and lifestyles of LGR ople, the manner in which such narratives are conceptualized and propagated jop atee by the idea of the big city. There are numerous narratives that postulaten city as the only option for making life livable for LGBT people. For example in words of Castells $(1983,138)$, San Franciso is the place 'where homos Xuals migrate for a few hours or many years to find themselves and to learn a language of freedom, sexuality, solidarity, and life - to 'come out' and to become gay'. Not only is the city turned into a space of socialization, liberation and anonymity, but it also becomes a place of political statements and the creation of LGBT subjectivities and the production of 'what we are'. In short, big cities have become the places that define what is known as LGBT. It is in the big cities where collective demands, the agendas of equality, lifestyles and media spaces promoting visibility are being constructed. That is why so many LGBT people see migration to the big city as an opportunity to participate in what they are meant to be, or should be, in order to achieve happiness or to join the 
community that, supposedly, they belong to. In the case of Girona, the idea of the big city and what it represents is associated fundamentally with Barcelona, 100 kilometers away, and 38 minutes by train.

Attempts are often made to transpose the big-city conceptions of LGBT life to smaller cities too, by constructing success stories based on the phenomenon of migration. This is the case of Pol, one of our participants who, when talking about an ex-partner who migrated to Barcelona said that 'he went off to live in Barcelona and become totally free'. However, we need to ask whether such liberation can be an immediate, permanent and individual act? When LGBT people get off the train in Barcelona, are that ready liberated? Can liberation be reduced to a distance of 100 kilometers? In regf fiberation is a subjective exercise associated with values, expectations and exponence, but which, in turn, is mediated by social, cultural, geographical and diachro ic gontexts. There is, therefore, no unique form of liberation, no definitive state oeilg 'liberated', and no unique space to become so. The big cities are not an essentideyent of sexual liberation for LGBT people. Big cities are still a possible senatio for the accumulation of experiences and identity construction, but b occur in other spaces. Indeed, Girona itself can become be a space whoth rs, an find 'liberation', as is the case with Pau, who considers his arrival in the city from his homeland as helping him to be more open since: 'When I arrived six yers a o, I saw many lesbians, I mean, lesbian couples who were holding hands. Tha a a big surprise for me, and a very pleasant one.' In terms of productivity, we say that Girona exports sexiles, but it is also welcoming of LGBT people from therritories. This statement is not intended to put those who leave and those whoting an equal footing in order to finally defend some kind of self-regulatige id id migration, but rather to challenge the idea that LGT people from mall 3 migrate en-masse to the big city to become part of the dynamics of such places, because the reality is that there are also LGBT people in small cities and rural environments. What happens is that their experiences are not made visible. That is to say, it is false that migration is an inevitable life project for LGBT people. Some people do migrate as a means to find sexual liberation, but many others cannot conceive of spending their lives among the great urban sprawl.

The big city in the West is seen as a dynamic place, while the small city, in contrast, is thought to be static and stuck in the past. However, the reality is that the dynamics of social transformation affect all urban environments, regardless of their size. 
Over the years, no society remains the same (Podmore 2016). Changes arise throughout the different phases of our lives, our personal experiences and social relationships, as they do through political initiatives, the demands of LGBT organizations and transformations in laws, among other things. In this sense Laura refers to this change in Girona when she explains that: 'Nowadays, yes, I do sometimes give Rebecca a kiss, or I take hold of her like this [makes a gesture with the hand] and, before, I couldn't do that naturally. I think there has been a lot of progress in Girona and in Barcelona as well.' In fact, Xavier recounts that Girona in the 1980s was a gloomy, provincial city, with no gays or lesbians visible at all: 'The gays and lesbians of Girona either lived a double life or liwaduside the city [...]. People used to go to Barcelona at weekends and then return on Monday as if nothing had happened. Things have been evolving; the whole of talan soerety has evolved.' Many of the other people interviewed also ment oned these changes, highlighting the major transformation and significant increase misibility compared to earlier periods.

\section{Myth and reality of violence outside the bits
Although LGBT representations and practices are over-represented by} big city ideas, this does not mean hat all sych practices and representations are simply replicated in all the cities arourd world; they also involve reintegrating and resignifying local notions of \&uyanty in socialization processes (Cáceres Feria and Valcuende del Río 2014. Varyez del Aguila 2014). Personal trajectories, social class and origin must alsa taken into account (Manalansan 2015). In terms of sexual diversity, the bigitures universal and individual at the same time, without one contradictinger. That is to say, the big city may be the space for LGBT represantatio. hut the way this representation occurs is different in each city (Muller 2016). Pitges, for example, with a population of 28,969 is a town in which gay tourism has a very significant economic and social impact (Institut Català d'Estadística 2019). The town is represented in the collective imagination as being very LGBT-friendly with high numbers of tourists, especially gay, who come to the town in summer in search of spaces of socialization, representation and recognition. In contrast, despite having a significantly higher population than Sitges, Girona is not perceived as particularly LGBTfriendly. This is because the representation of sexual diversity has been constructed in totally different ways in Sitges and Girona. Therefore, when considering the sexual representation of urban geographies, we must reflect not only on the Western dynamics 
constructed in big cities, but also the local dynamics that construct the social and cultural character of each territory.

In this sense, there is no doubt that the size and type of the city you live in has a considerable influence on the way relationships and experiences between people are shaped. Nevertheless, what is problematic is the idea that there exists a direct relationship between the size of the town and the degree of hostility towards LGBT people. None of the people interviewed recounted any actual physically violent situations; however, all of them have suffered, at some point in their lives, have experienced some degree of discrimination and distress motivated by the fact that they are LGBT people. Samoroport distressing situations in the public space: 'I was saying goodbye to a girl, $1 \mathrm{jke}$, Bye. Hope it all goes well" and I gave her two or three little kisses here [she pints or her neck], okay? And a waiter who saw us said -You made me all horny ju lodking at you'(P2). Other people have avoided talking about their gender identryn family settings in anticipation of negative consequences: 'My family does nhow about it. But if they did know, I wouldn't get any support. [...] They say fa ly doad things about trans people. If I tell them I'm one... who knows what' hapnery? Other participants talked about discrimination in the workplace, such Marc, who described his experience in the company he worked for, where beard heonstant stream of derogatory comments relating to sexual and gender diversity ynd 'you couldn't express yourself as you really were. You had to hide; they mese jokes and you had to keep it hidden. [...] But you end up getting used to hiding itbe-yse, if you don't, what can you do?' Another work-related problem was described to the is a social worker and, in his work, he frequently hears homophobic and omments, and he is directly affected by the homophobes but, he says, 'you hou we with it because you are the professional. You could maybe say some-1hing b.t the end of the day, you are the one attending to that person'. There are also th 3 ho have experienced discrimination in school environments, such as Pol, who lived through episodes of bullying at school for years. There were even forms of violence dressed up as teaching good manners, such as when Neus, was told by a relative to 'be more feminine' to help her make her sexuality more coherent with her gender. Yet, despite the distress caused by such episodes, none of the participants established a direct relationship with the size of the city. In fact, Diana explains that, in Girona 'I have not had any problems beyond the typical one of people who look at you on the street because they don't know what is going on. But that is just as typical here as it is in Barcelona.' The manner in which violent episodes arise is highly varied, and affected by a range of 
circumstances and contexts, but in our study no data was found associating hostility towards LGBT people with the fact they took place in a small city. This leads us to believe that the root of anti-LGBT feeling is not in the size of the city but in the patriarchal structures, the logic of binary gender and the heterosexuality imposed on social relations. Migrating to Barcelona, away from their hometown environments, may mean escaping from some of the violence and hostility which can occur in the proximity of family or local communities, but in no way does it free the individuals from the social structures that support such violence and hostility.

\section{Livable lives in small cities}

The stories of our participants were not restricted to violencen otivated by their sexual orientation or how they felt or expressed their gender. They also recounted episodes of solidarity, understanding, mutual recognition, as wet1 is pleasure and wellbeing. Therefore, we should ask ourselves: To what extent oes the context of being in a small city influence these experiences? What are the pric.larities of LGBT experiences in small cities?

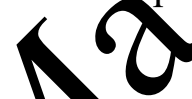

To answer these questions, we phentect on at least three elements which, in my view, are essential to understanding thespecific case of Girona. We also need to reexamine some of the myths asso ian $y$ with small cities in terms of sexual and gender diversity. The first element is 2 high degree of public exposure to acquaintances, and the resulting social controlang co-inhabitants. Although it is difficult to measure the exact extent of publis oo ure among the inhabitants of a city, in reality, people in Girona are quite on hom seen or recognized by someone they know in public spaces. This significatects how LGBT people express themselves in public, since there is constant sur ance regarding gender norms and sexual orientation. The LGBT people of Gird know this and thus deploy a set of measures that favor anonymity, or at least contribute to invisibility: not showing affection in public, avoiding certain attitudes, behaviors or practices that may 'betray' their sexual orientation or gender identification, or not going to places in the city that are associated with LGBT people. Nevertheless, this level of control and recognition also provides a greater sense of security for some LGBT people in the city because it also limits the options for aggression in public places. If an attack occurs, it is much easier to identify the perpetrators than it would be in a big city, because there is an increased chance that the victim or a bystander will be able to identify them. And this is not an insignificant factor if we take into account that, according to a 
survey by the Fundamental Right Agency (2014), 53\% of the most serious hate crimes committed in Europe against LGBT people take place in cafeterias, restaurants, pubs, clubs, public transport, street, squares, car parks or other public spaces. In contrast, the public visibility of LGBT people tends to permeate a large part of their social life, although it is true that coming out is a complex, recurring experience for all LGBT people and 'the closet is structured in such a way that you are never simply either in or out' (Eribon 1999). In small cities like Girona, LGBT people have more difficulties with resignification once their sexual orientation or gender identity is known by their wider social circle, since it can soon become vox populi and affect their professionol caer or hinder access to jobs, for example. In this sense, Arnau, a top executive in tho ady ads that he must 'tread very carefully' at work with the idea of being 5 . Swcial control regarding sexuality and gender is a lived reality for some of our i tery ewees in Girona. Foucault (1976) assures us that the only possible history of aexuraliy is one of its control and regulation. In the same vein, Plummer (1984, 228) C.ims that 'there is no society where sexual experiences proceed untrammeled by so ial tegulations - complete sexual freedom exists exclusively in the libertarian's reand ayd the moral reformer's nightmare'. For this reason, thinking of social contre sna -town issue, is little more than another way of negating the complete set contron that operate across society as a whole.

The second of the elem nts ye must analyze concerns access to sexual relationships and interactions. $\mathcal{C}$ should be pointed out, however, that the importance given to sexual relationshins varies significantly among the participants, depending on whether they are leshian gys, bisexuals or trans, as well as on other aspects, such as age, the person' ${ }^{2}$ ibi) lty, and other interests. For example, Maria, a bisexual woman reports that 'sex is unimportant regarding the person; what's important is the perso thems thes, their values, what they feel about me'. In contrast, among gay men, sex is ofer present. Carles explains that 'Fucking is easy. The complicated thing is having a drink 'afterwards.' Along the same lines, Maxi, who has a very active sex life, says he has no problems finding sex whenever he wants it in Girona. Also, Pau declares that 'the biggest community in Girona is the sexual community [...] just go on Grindr [the mobile dating app for men] and you can meet half of Girona. If you want sex, you'll get it right away.' Another participant, Martín, said much the same thing. The difficulty in finding sexual partners in a small city has long been used to explain sexile to a big city, but what many of the participants in this research are saying shows that, in a city like Girona, men who want to have sex with other men can do so without any great difficulty; they see 
access to sexual relationships as a relatively simple activity. Of course, in both large and small cities, the internet and mobile apps have become the principle tools for finding sexual partners. Therefore, although sex remains an important issue, especially for men who have sex with other men, people who live in small cities have strategies that allow them access to sexual relationships.

The third element we now discuss is the idea of LGBT loneliness associated with small cities, which is found in many of the narratives generally about LGBT life. We must first acknowledge the many obstacles that LGTB people have had to face in trying to make the best of their lives in Girona, and that some have found it too difult to construct LGBT support networks and, consequently, have gone into sexile 1. Batcelona. It is, nevertheless, also true that others have organized their social life thoul the ir sexual orientation or gender identity creating difficulties. While LGBT laces of socialization and representation in the big city include LGBT bars and orgentzations promoting sexual liberation, in cities such as Girona, LGBT people seek othe styategies that allow them to live their lives outside the classic LGBT circuits. Mâ/ the people interviewed have found other spaces and groups with whom shareir affinities and pursuits, where they can express themselves freely as wholly or partially LGBT, or predsminanty yeterosexual. In other words, LGBT people also find areas of solidarity in soci ny yorks that are not exclusively LGBT orientated. The so-called 'LGBT commun 7 s a place of refuge is not really an option for many of

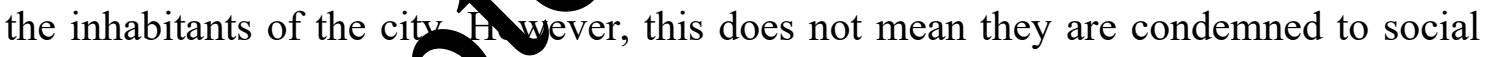
isolation. Assuming the natural' space for LGBT socialization is confined to LGBT bars and collectius en rooted in the big city, is a mistake that, once again, makes invisible may experiences and, to paraphrase Butler, livable lives. As Carles says 'Girom is a that doesn't make LGBT social life difficult, but it doesn't promote it, either'

However, for some of the people interviewed, Girona is still 'a very straight and conservative city' (Nora). Many of them still find difficulties or limitations in expressing their sexual orientation or gender identity in certain areas of their lives, they are also aware that if they lived in a large city, they would have to face other kinds of challenges. That is why LGBT people find a variety of reasons to live in a small city like Girona. There are experiential reasons, described by Sara, for example, when she says Girona 'has produced the most wonderful and the most painful things of her life', showing that, for her, the links with a territory do not depend on its beauty or its material resources, but 
above all on the relationships that have been established there. There are environmental reasons: 'It is so green and there are no buildings. We live in an area with a small forest next door, it doesn't feel like we are in a city; no cars, no noise at night, it is very quiet. I'm in love with Girona!' (Claudia). There are practical reasons, since there are plenty of public services, restaurants, bars, etc., and it is easy to maintain contacts with daily social networks: 'I can afford myself the luxury of meeting up with my friends almost every day. I go to the bar on my own and I always meet friends' (Arnau). There are reasons related to safety, since some feel that 'there aren't really any problems of discrimination' (Ona). There are geographical reasons, because it means you can live a quinf sejin a small city relatively close to Barcelona. As Neus says 'Girona is not perfact there are many things I like. I know the city, I can manage here, and I really like the surroundings.' Yet, Pau emphasizes that in Girona 'there is no gay neighborhoo with a concentration of LGBT people, like there is in Barcelona or Madrid. We pre singre spread about here, and I find that logical [...]. In Girona you can't feel part of anmunity [of LGBT people] because there is no community.' So, the dominant dis ouse associated with the LGBT community is connected to the imaginary of he g Mty, yet has a tenuous connection with other experiences of sexual and ge der diy erty among people who do not aspire to live in large urban environments.

\section{Conclusions}

The dominant discousg associates LGBT communities with large metropolitan centers works thake invisible, disparage and underestimate the experiences of LGBT people who do not live in these social settings. LGBT experiences are highly diverse, they occur ingultiple locations and cannot be reduced to an only large urban center. The hegemony of the big city in academic study and discussion of sexual and gender diversity must be reconsidered to include other contexts where the 'LGBT community' can be found; it must include places where such a community is neither operative nor, indeed, representative of the diversity of experiences, discourses and social practices. Experiences of sexuality and gender are not only shaped by the recurrent questions that permeate sociology, anthropology or feminist and LGBT studies which, depending on the disciplinary or political view, prioritize the typical variables of social class, gender, age, sexual orientation or culture. When analyzing the dimensions of power that shape sexual 
and gender relationships, as Johnston (2018) pointed out, we must also incorporate urban and territorial references as variables that shape the experiences and circumstances of LGBT people. Integrating territorial references implies considering the global and local dynamics of each urban context as it intersects with class, race, gender and sexual orientation. Only then can we carry out a more careful and rigorous analysis of social realities.

Finally, this research allows us to abandon the idea that sexile is the inevitable course of action that LGBT people must take if they are to cope with thexual orientation or gender identity. Although we recognize that many LGBT peopr end up choosing life in the big city, it is not necessarily the obligatory destinst or them all, nor is it something that all LGBT people residing in small cities There are many factors involved in choosing where to live and sexual and gender issues play a fundamental role, they are not the only on inolved. Social control permeates the experiences of LGBT people. However a scale that measures such social control as greater or lesse ding on the size of the city in question is, besides being tendentious, in for this type of research. The subjectivity of each person in their own carto plays a key role and this must be factored in, if a rigorous analysis is to be mat. Therefore, it is time to put an end to the negative predictions of what awaits LGBT Cone who do not reside in large cities. Despite the difficulties, many of them crasticient reasons to live in small cities where they find their spaces of socializat on, orcoexistence and also, sometimes, of recognition.

Acknowled rements

I want to or rek Rights, Equality and Citizenship Programme for the funding to Diverc y project. I also would like to thank my colleague Olga Jubany for involving me in this exciting project. I am also grateful to Pilar Albertin, Joan Bestard, Antonia Dorado, Jordi Más, Malin Roiha and Núria Sadurní, as well as the partners' teams for their inputs and discussions about LGBT in small and medium cities. Finally, I would like to specially thank all the participants for their interest and engagement.

\section{References}


Abelson, Miriam J. 2016. “'You Aren’t from around Here': Race, Masculinity, and Rural Transgender Men." Gender, Place \& Culture 23 (11): 1535-46. https://doi.org/10.1080/0966369X.2016.1219324.

Abraham, Julie. 2009. Metropolitan Lovers: The Homosexuality of Cities. Minneapolis: University of Minnesota Press.

Aldrich, Robert. 2004. "Homosexuality and the City: An Historical Overview." Urban Studies 41 (9): 1719-37. https://doi.org/10.1080/0042098042000243129. Annes, Alexis, and Meredith Redlin. 2012. "Coming out and Coming Back: Rura Gay Migration and the City.” Journal of Rural Studies 28 (1): 56-68. https://doi.org/10.1016/j.jrurstud.2011.08.005.

Baley, Robert. 1998. Gay Politics. Urban Politics. Identity and ECnonnics in the Urban Setting. New York: Columbia University Press.

Bech, Henning. 1997. When Men Meet: Homosexuality no Mernity. Chicago: The Univesity of Chicago Press.

Bell, David. 2000. "Farm Boys and Wild Me Rurfilyy, Masculinity, and Homosexuality." Rural Sociology (4):[54/61. https://doi.org/10.1111/j.15490831.2000.tb00043.x.

Bell, David, and Jon Binnie. 2004. Ar henticating Queer Space: Citizenship, Urbanism and Governance." Urban PRidjes 41 (9): 1807-20. https://doi.org/10.1080/0 42098042000243165.

Bell, David, and Gill anthe. 1995. "Introduction: Orientations." In Mapping Desire: Geographigon Seduatuies, edited by David Bell and Gill Valentine, 1-27. London-1 dge.

Binn Jon. 4he Globalization of Sexuality. London: Sage.

Brown Gavin. 2008. "Urban (Homo)Sexualities: Ordinary Cities and Ordinary Sexualities." Geography Compass 2 (4): 1215-31. https://doi.org/10.1111/j.17498198.2008.00127.x.

Gay Lives.” Journal of Homosexuality 59 (7): 1065-72. https://doi.org/10.1080/00918369.2012.699851.

Browne, Kath. 2008. "Imagining Cities, Living the Other: Between the Gay Urban Idyll and Rural Lesbian Lives." The Open Geography Journal 1 (1): 25-32. https://doi.org/10.2174/1874923200801010025. 
2011. “Beyond Rural Idylls: Imperfect Lesbian Utopias at Michigan Womyn's Music Festival." Journal of Rural Studies 27 (1): 13-23.

https://doi.org/10.1016/j.jrurstud.2010.08.001.

Browne, Kath, and Jason Lim. 2010. "Trans Lives in the "Gay Capital of the UK."

Gender, Place \& Culture 17 (5): 615-33.

https://doi.org/10.1080/0966369x.2010.503118.

Bryant, Lia, and Barbara Pini. 2011. Gender and Rurality. New York: Routledge. https://doi.org/10.4324/9780203848289.

Cáceres Feria, Rafael, and José María Valcuende del Río. 2014. “Globalizac Diversidad Sexual, Gays y Mariquitas En Andalucía." Gazeta de Artroplogia 30 (3).

Callander, Denton, Christy E. Newman, and Martin Holt. 2015."Setual Racism Really Racism? Distinguishing Attitudes Toward Sexual ractm and Generic Racism Among Gay and Bisexual Men." Archives of exylul Behavior 44 (7): 1991-2000. https://doi.org/10.1007/s10508-015-487.3.

Carrillo, Héctor, and Jorge Fontdevila. 2014. Border rossings and Shifting Sexualities among Mexican Gay Lemigrdnt Men: Beyond Monolithic Conceptions.” Sexualities 17 @): 919-88. https://doi.org/10.1177/1363400 4552248.

Casey, Mark. 2016. "Even Podrefays Travell: Excluding Low Income Gay Men from Understandings of Gay wyrism." In Classed Intersections: Spaces, Selves, Knowledges, editea vette Taylor, 181-98. New York: Routledge.

Castells, Manuelder Therty and the Grassroots: A Cross-Cultural Theory of Urban Soctovements. London: Edward Arnold.

Chanaion, 1 and Graeme Hugo, eds. 2016. New Forms of Urbanization: Beyond th Urban-Rural Dichotomy. London and New York: Routledge.

Chauncey, George. 1994. Gay New York: Gender, Urban Culture, and the Making of the Gay Male World 1890-1940. Nueva York: Basic Books.

Chávez, Karma R. 2011. "Identifying the Needs of LGBTQ Immigrants and Refugees in Southern Arizona." Journal of Homosexuality 58 (2): 189-218. https://doi.org/10.1080/00918369.2011.540175.

Doan, Petra L. 2007. "Queers in the American City: Transgendered Perceptions of Urban Space.” Gender, Place and Culture 14 (1): 57-74. https://doi.org/10.1080/09663690601122309. 
2010. "The Tyranny of Gendered Spaces - Reflections from beyond the Gender Dichotomy." Gender, Place \& Culture 17 (5): 635-54.

https://doi.org/10.1080/0966369x.2010.503121.

Doderer, Yvonne P. 2011. “LGBTQs in the City, Queering Urban Space.” International Journal of Urban and Regional Research 35 (2): 431-36.

https://doi.org/10.1111/j.1468-2427.2010.01030.x.

Duggan, Lisa. 2002. "The New Homonormativity: The Sexual Politics of

Neoliberalism.” In Materializing Democracy, edited by Russ Castronovo and Dana

D. Nelson, 175-94. Durham and London: Duke University Press.

Foucault, Michel. 1976. Histoire de La Sexualité I. La Volonté de Savoir

Gallimard.

Fountain-Stokes, Lawrence La. 2004. "De Sexilio(s) y Diáspora(s Hotnosexual(Es)

Latina(s): Cultura Puertorriqueña y Lo Nuyorican Queer. Date Feminista 29:

$138-57$.

Fundamental Rights Agency. 2014. European Union Lsbun, Gay, Bisexual and

Transgender Survey. Main Results. Lux nbofrg.Publications Office of the

European Union. https://doi.org/102011/37,89.

Gorman-Murray, Andrew, and Catherine J. Yash. 2017. "Transformations in LGBT

Consumer Landscapes and Le sur Spaces in the Neoliberal City." Urban Studies

54 (3): 786-805. https://d_Fror/10.1177/0042098016674893.

Gray, Mary L., Colin R. John and and Brian J. Gilley, eds. 2016. Queering the

Countryside. Newiers in Rural Queer Studies. New York-London: New

York Univensit D.tss.

Guzmán, Mgac 197. ““Pa’ La Escuelita Con Mucho Cuida’o y Por La Orillita”: A

wurney ough the Contested Terrains of the Nation and Sexual Orientation." In

P. Rerto Rican Jam: Rethinking Colonialism and Nationalism, edited by Frances

Negrón-Muntaner and Ramón Grosfoguel, 209-28. Minneapolis: University of

Minnesota Press.

Halberstam, Judith. 2005. In a Queer Time and Place: Transgender Bodies, Subcultural Lives. New York: New York University Press.

Herring, Scott. 2010. Another Country. Queer Anti-Urbanism. New York-London: New York University Press.

Hibbins, Ray. 2005. "Migration and Gender Identity among Chinese Skilled Male

Migrants to Australia." Geoforum 36 (2 SPEC. ISS.): 167-80. 
https://doi.org/10.1016/j.geoforum.2003.10.003.

Higgs, David, ed. 1999. Queer Sites : Gay Urban Histories since 1600. New York: Routledge.

Hindle, Paul. 1994. "Gay Communities and Gay Space in the City.” In The Margins of the City. Gay Men's Urban Lives., edited by Stephen Whittle, 7-25. Aldershot: Arena.

Hubbard, Phil. 2012. Cities and Sexualities. New York: Routledge.

Hubbard, Phil, and Eleanor Wilkinson. 2015. "Welcoming the World? Hospitality, Homonationalism, and the London 2012 Olympics." Antipode 47 (3): 508 05 https://doi.org/10.1111/anti.12082.

Instituto de Estadistica de Catalunya. 2019. Població en 2018 https://www.idescat.cat/emex/

Irazábal, Clara, and Claudia Huerta. 2016. "IntersectionalityanurPanning at the Margins: LGBTQ Youth of Color in New York." Gen Place and Culture 23 (5): 714-32. https://doi.org/10.1080/0966369X.2W5.X58755.

Johnston, Lynda. 2018. "Intersectional Femi and aleer Geographies: A View from 'down-Under." Gender, Place \& lturd https://doi.org/10.1080/0966369X.201/4460329.

Kanai, J. Miguel. 2014. "Whither ueg yorld Cities? Homo-Entrepreneurialism and Beyond." Geoforum 56: 1 8. https://doi.org/10.1016/j.geoforum.2014.06.012. Kazyak, Emily. 2011. "Disur.jug Cultural Selves: Constructing Gay and Lesbian Identities in Rura 1 cales." Qualitative Sociology 34 (4): 561-81.

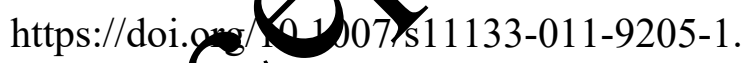

Kuhar, Romas Alenka Švab. 2014. "The Only Gay in the Village? Everyday Life fGays Lesbians in Rural Slovenia." Journal of Homosexuality 61 (8): 10911.16. Rttps://doi.org/10.1080/00918369.2014.872492.

Langarita Adiego, Jose Antonio, and Maria Alejandra Salguero Velázquez. 2016.

"Sexiled in Mexico City: Urban Migrations Motivated by Sexual Orientation." Bulletin of Latin American Research, July. https://doi.org/10.1111/blar.12523. Manalansan, Martin F. 2015. "Queer Worldings: The Messy Art of Being Global in Manila and New York." Antipode 47 (3): 566-79.

https://doi.org/10.1111/anti.12061.

Martinez-San Miguel, Yolanda. 2011. “'Sexilios’: Hacia Una Nueva Poética de La Erótica Caribeña.” America Latina Hoy, no. 58: 15-30. 
Mcglynn, Nick. 2018. "Slippery Geographies of the Urban and the Rural : Public Sector LGBT Equalities Work in the Shadow of the " Gay Capital ." Journal of Rural Studies 57: 65-77. https://doi.org/10.1016/j.jrurstud.2017.10.008.

McPhail, Beverly A. 2008. "Re-Gendering the Social Work Curriculum: New Realities and Complexities." Journal of Social Work Education 44 (2): 33-52. https://doi.org/10.5175/JSWE.2008.200600148.

Muller, Tiffany. 2016. "Visibility on Their Own Terms? LGBTQ Lives in Small Canadian Cities." In The Routledge Research Companion to Geographies of Sex and Sexualities, edited by Gavin Brown and Kath Browne, 37-44. New Routledge.

Nash, Catherine J. 2010. “Trans Geographies, Embodiment and Expen Snce Gender, Place \& Culture 17 (5): 579-95. https://doi.org/10.1080/096 369k.2010.503112. _. 2013. "The Age of the 'Post-Mo'? Toronto's Gay Killage and a New Generation." Geoforum 49: 243-52.

https://doi.org/10.1016/j.geoforum.2012.11.023

Nash, Catherine J., and Andrew Gorman-Mu $20 y$. "Lesbians in the City:

Mobilities and Relational Geograp "Jou, hal of Lesbian Studies 19 (2): 173-

91. https://doi.org/10.1080/10294160.2015.969594.

—. 2017. "Sexualities, Subjec ivi os and Urban Spaces: A Case for Assemblage Thinking." Gender, Placequd) Culture 24 (11): 1521-29.

Plummer, Ken. 1984. "Sexua Diversity: A Sociological Perspective." In The Psychology of Saxu Diversity, edited by Kevin Howells, 219-53. Oxford: Blackwell pubbivater. $>$

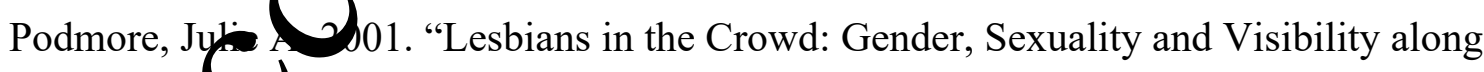
Montre. Boul. St-Laurent." Gender, Place and Culture 8 (4): 333-55.

h/ps://oi.org/10.1080/09663690120111591. 2016. “Disaggregating Sexual Metronormativities: Looking Back at 'Lesbian' Urbanism." In The Routledge Research Companion to Geographies of Sex and Sexualities, edited by Gavin Brown and Kath Browne, 21-28. New York: Routledge.

Podmore, Julie A., and Line Chamberland. 2015. "Entering the Urban Frame: Early Lesbian Activism and Public Space in Montréal.” Journal of Lesbian Studies 19 (2): 192-211. https://doi.org/10.1080/10894160.2015.970473.

Rodó de Zárate, Maria. 2015. "Young Lesbians Negotiating Public Space: An 
Intersectional Approach through Places." Children's Geographies 13 (4): 413-34. Rosenberg, Rae. 2017. “The Whiteness of Gay Urban Belonging: Criminalizing

LGBTQ Youth of Color in Queer Spaces of Care." Urban Geography 38 (1): 13748. https://doi.org/10.1080/02723638.2016.1239498.

Sibalis, Michael. 2004. "Urban Space and Homosexuality: The Example of the Marais, Paris' 'Gay Ghetto.”' Urban Studies 41 (9): 1739-58.

https://doi.org/10.1080/0042098042000243138.

Smith, Geoffrey. 2012. "Sexuality, Space and Migration: South Asian Gay Men in Australia." New Zealand Geographer 68 (2): 92-100. https://doi.org/10.1111/j.1745-7939.2012.01229.x.

Vasquez del Aguila, Ernesto. 2014. Being a Man in a Transnational Afrld. The Masculinity and Sexuality of Migration. Being a Man in a Tr nsnutional World:

The Masculinity and Sexuality of Migration. London and Yen York: Routledge. https://doi.org/10.4324/9781315886565.

Weston, Kath. 1995. "Get Thee to a Big City." GLQ. Jostrnal of Lesbian and Gay Studies 2: 253-77.

Wienke, Chris, and Gretchen J. Hill. 20 “D pes, Place of Residence Matter? RuralUrban Differences and the WNlbeing fGay Men and Lesbians." Journal of Homosexuality 60 (9): 1256-9. Sps://doi.org/10.1080/00918369.2013.806166.

Table 1: Socio-demographic ejails of the LGBT people who were interviewed and/or participated in the gran $p$ isdissions $(*$ denotes people interviewed / $\neq$ denotes discussion

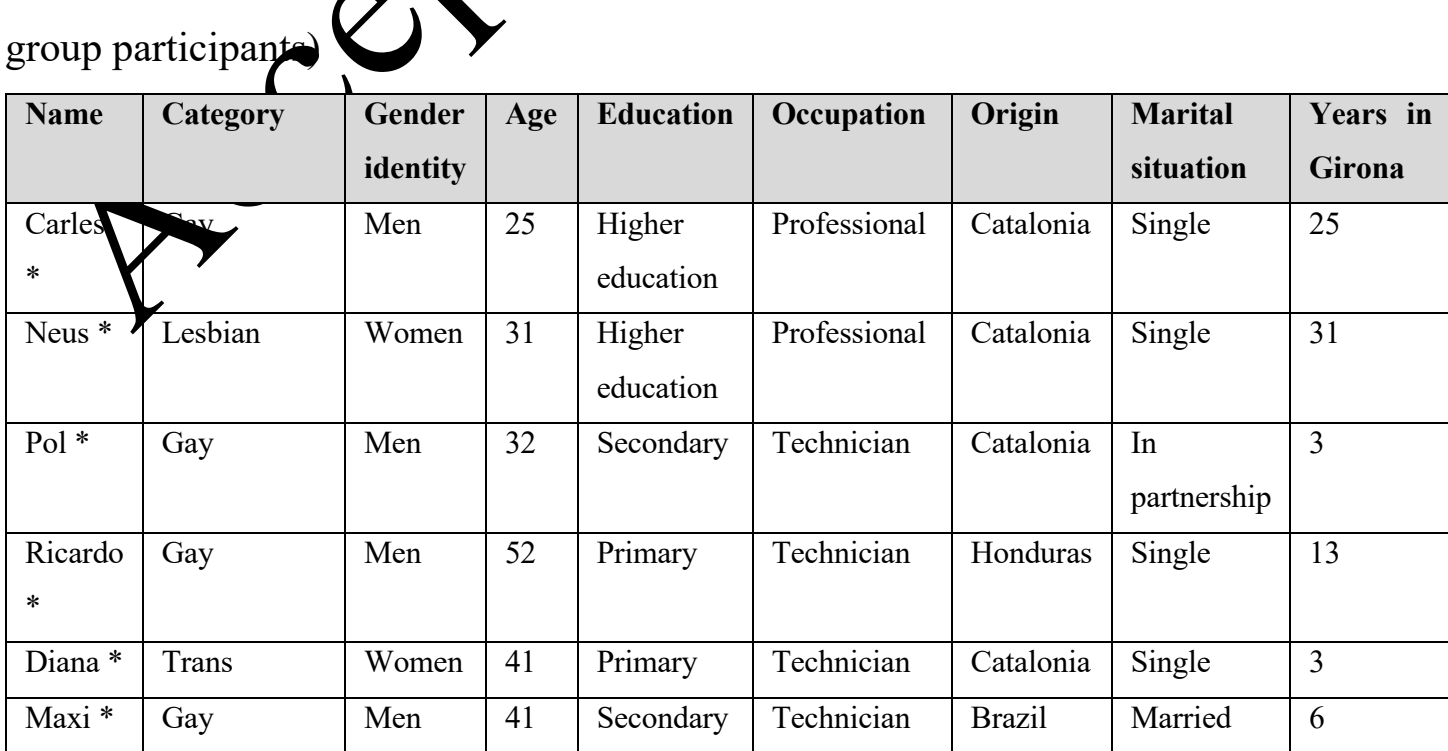




\begin{tabular}{|c|c|c|c|c|c|c|c|c|}
\hline Nora* & Lesbian & Women & 58 & Primary & $\begin{array}{l}\text { Personal } \\
\text { service } \\
\text { worker }\end{array}$ & Catalonia & Married & 23 \\
\hline Sara * & Lesbian & Women & 35 & $\begin{array}{l}\text { Higher } \\
\text { education }\end{array}$ & Professional & Spain & Married & 2 \\
\hline Marc * & Gay & Men & 48 & $\begin{array}{l}\text { Higher } \\
\text { education }\end{array}$ & Unemployed & Catalonia & Single & 48 \\
\hline Lucia* & $\begin{array}{l}\text { Trans } \\
\text { (partner } \\
\text { Carlota) }\end{array}$ & Women & 51 & Secondary & Technician & Spain & Married & 28 \\
\hline $\begin{array}{l}\text { Carlota } \\
*\end{array}$ & $\begin{array}{l}\text { Heterosexual } \\
\text { (partner } \\
\text { Lucia) }\end{array}$ & Women & -- & Unknown & Unknown & Catalonia & Married & \\
\hline Ona * & Lesbian & Women & 26 & $\begin{array}{l}\text { Higher } \\
\text { education }\end{array}$ & Professional & Catalonia & & \\
\hline Maria * & Bisexual & Women & 23 & Secondary & Professional & & & 2 \\
\hline Laura * & Bisexual & Women & 55 & Higher & $\mathrm{P}$ & & Married & 6 \\
\hline $\begin{array}{l}\text { Claudia } \\
*\end{array}$ & $\begin{array}{l}\text { Lesbian } \\
\text { (partner } \\
\text { P14B) }\end{array}$ & Women & 24 & Secondary & & atalonia & $\begin{array}{l}\text { In } \\
\text { partnership }\end{array}$ & 5 \\
\hline $\begin{array}{l}\text { Carlota } \\
*\end{array}$ & $\begin{array}{l}\text { Bisexual } \\
\text { (partner } \\
\text { Claudia) }\end{array}$ & Women & 30 & & ntary & Catalonia & $\begin{array}{l}\text { In } \\
\text { partnership }\end{array}$ & 5 \\
\hline Arnau & Gay & Men & & & Manager & Catalonia & Single & 40 \\
\hline Sofia $\neq$ & Lesbian & & & Secondary & Technician & Catalonia & Single & 20 \\
\hline $\begin{array}{l}\text { Martín } \\
\neq\end{array}$ & Gay & & 30 & $\begin{array}{l}\text { Primary } \\
\text { school }\end{array}$ & $\begin{array}{l}\text { Services } \\
\text { worker }\end{array}$ & Catalonia & Single & 30 \\
\hline $\mathrm{Pr}$ & & Men & -- & $\begin{array}{l}\text { Higher } \\
\text { education }\end{array}$ & Professional & Catalonia & $\begin{array}{l}\text { In } \\
\text { partnership }\end{array}$ & 6 \\
\hline $\begin{array}{l}\text { Mireia } \\
\neq\end{array}$ & Lesbian & Women & 22 & $\begin{array}{l}\text { Higher } \\
\text { education }\end{array}$ & Unemployed & Catalonia & Single & 5 \\
\hline Joana $\neq$ & Queer & Queer & 19 & $\begin{array}{l}\text { Secondary } \\
\text { School }\end{array}$ & Student & Catalonia & Single & 2 \\
\hline
\end{tabular}

Table 2: Main details of the stakeholders who were interviewed and/or participated in the group discussions (* denotes people interviewed / denotes discussion group participants)

\begin{tabular}{|l|l|l|}
\hline Name & Role in service & Service \\
\hline
\end{tabular}




\begin{tabular}{|c|c|c|}
\hline Martina* & Police & Autonomous Police \\
\hline Esteban * & Doctor & Heath Center \\
\hline Guillermo * & Psychologist & Youth Health Service \\
\hline Aitana * & Service coordinator \& Psychologist & $\begin{array}{l}\text { HIV detection and } \\
\text { guidance }\end{array}$ \\
\hline Xavier * & President of local section & Gay NGO \\
\hline Lucas * & School director & Primary School \\
\hline Miguel * & Owner & LGBT Business \\
\hline Marta * & Decision maker & City \\
\hline Ernesto * & Social worker & \\
\hline Aniol * & Journalist & \\
\hline Manuel * & Prosecutor & Getices \\
\hline Alejandra $\neq$ & Women Section coordinator & \\
\hline Eudald $\neq$ & Regional coordinator of LGBT issues & $\begin{array}{l}\text { ry of Labor, Social } \\
\text { s and Family }\end{array}$ \\
\hline Anna $\neq$ & Polic & City Council \\
\hline Carla $\neq$ & Vic & Ministry of Justice \\
\hline Dolores $\neq$ & Psychologist & $\begin{array}{l}\text { Institut Català de les dones } \\
\text { [Catalan Institute for } \\
\text { Women] }\end{array}$ \\
\hline Carmen $\neq$ & $D=1$ & Health network \\
\hline Nestor $\neq$ & ordinator & City council \\
\hline Isabel $\neq$ & ator of Health program & City council \\
\hline
\end{tabular}

